Mohd Khairul Naim, "Kajian Kritis Hubungan Agama \& Pemikiran Terorisme," Afkār Vol. 19 Issue 2 (2017): 73-106

\title{
KAJIAN KRITIS HUBUNGAN AGAMA DAN PEMIKIRAN TERORISME*
}

\section{CRITICAL STUDIES ON RELIGION AND TERRORISM}

\section{Mohd Khairul Naim Che Nordin}

Department of `Aqidah \& Islamic Thought. Academy of Islamic Studies. University of Malaya. 50603. Kuala Lumpur. Malaysia.

Emel: khairulnaim@um.edu.my

\begin{abstract}
Khulasah
Pemikiran terorisme merupakan suatu faham yang melihat pendekatan keganasan adalah diperlukan sebagai suatu kaedah untuk mencapai sesuatu tujuan. Abad ke-21 menyaksikan istilah ini mula mendapat perhatian serius oleh masyarakat dunia dengan berlakunya peningkatan kegiatan keganasan di negaranegara Barat dengan kemuncak kepada perlakuan tersebut adalah seperti yang terjadi di New York, Amerika Syarikat pada tahun 2001 dan London, Britain pada 2005 serta rangkaian serangan lain di lokasi berbeza sehingga kini. Tambahan pula, kewujudan pertubuhan terrorisme yang menggunakan nama agama serta menggunakan pendekatan keganasan bagi mencapai tujuan mereka seperti yang dilakukan oleh Islamic State of Iraq and al-Syam (ISIS), al-Qaeda, Abu Sayyaf dan lain-lain telah membuka dimensi perbincangan khusus hubungan agama dengan terorisme. Makalah ini mengaplikasikan pendekatan kualitatif melalui kaedah dokumentasi dengan secara khususnya merujuk dapatan-dapatan kajian yang telah dilakukan seperti oleh United Nations Office of Counter-Terrorism (UNOCT) dan Chicago Project on Security and
\end{abstract}

\footnotetext{
* Makalah ini merupakan versi kemas kini dari kertas kerja yang dibentangkan oleh penulis di The 4th International Conference on Human Sustainability anjuran Universiti Tun Hussein Onn Malaysia (UTHM) pada 1-2 November 2017 di Hotel Muzaffar, Melaka.
} 
Terrorism berkenaan kegiatan teroris. Bagi proses penganalisisan data, kajian menggunakan metode kualitatif deskriptif melibatkan metode induktif bagi menganalisis data dokumentasi dengan tumpuan khusus terhadap penyelidikan korelasi. Kajian menunjukkan kemunculan pemikiran terorisme dan kegiatan keganasan yang dilakukan bukanlah disebabkan oleh faktor agama tetapi atas faktor lain seperti kepentingan atau kelemahan peribadi, faktor politik yang lahir dari semangat nasionalisme dan aspek ekonomi. Agama hanya dijadikan sebagai justifikasi untuk mewenangkan pemikiran dan seterusnya tindakan tersebut. Kajian merumuskan bahawa perlu diletakkan suatu dikotomi jelas antara agama dengan terorisme. Perbuatan keganasan seseorang atas nama agama tidak mencerminkan dan mewakili penganut tersebut apatah lagi ajaran agama yang dianuti mereka. Makalah ini turut mencadangkan satu kajian khusus perlu dilakukan berkaitan perkembangan pemikiran terorisme di Malaysia serta implikasinya terhadap masyarakat masa kini.

Kata kunci: agama; terorisme dan teroris; factor; Islam.

\begin{abstract}
Terrorism is a thought that the approach of violence is needed as a means of achieving a goal. The beginning of the 21 st century saw this term have begun to get serious attention from the world community with the rise of terrorism activities in Western countries especially in New York, United States in 2001 and London, Britain in 2005 and other attacks in different locations until now. Furthermore, the existence of terrorism organizations using religious names and terrorism approaches to achieve their goals, such as the Islamic State of Iraq and al-Syam (ISIS), al-Qaeda, Abu Sayyaf and others have opened the dimension discussions of specific religious affiliation with terrorism. This paper applies qualitative approaches through documentation methodology in particular
\end{abstract}


referring to research findings that have been conducted by the United Nations Office of Counter-Terrorism (UNOCT) and the Chicago Project on Security and Terrorism on terrorist activities. For the data analysis, the study uses descriptive qualitative methods involving inductive methods for analyzing documentation data with a special focus on correlation investigations. Studies show that the emergence of terrorism is not caused by religious factors but on other factors such as personal weakness, the political factors that emerge from the spirit of nationalism and the factor of economic instability. Religion is only used as an excuse to justify the thoughts and actions of terrorism. The study concludes that there should be a clear dichotomy between religion and terrorism. The act of violence in the name of a religion does not reflect and represent other believers and their religious teachings. This paper also suggested that a special study should be done regarding the development of terrorism in Malaysia and its implications to the present society.

Keywords: religion; terrorism and terrorist; factor; Islam.

\section{Pendahuluan}

Sepanjang sejarah kemanusiaan, wujud penguasa yang berkuasa secara despotik dan menggunakan keganasan sebagai ancaman untuk menundukkan mereka di bawahnya. Pendekatan ini digunakan oleh Sargon of Akkad, penguasa empayar Babylon dan ramai lagi. ${ }^{1}$ Terorisme terus wujud sehingga masa kini kerana keberhasilan tujuan utamanya iaitu untuk menundukkan dan mengawal psikologi manusia. Impak psikologi dari

\footnotetext{
${ }^{1}$ Lihat Marlies Heinz, "Sargon of Akkad: Rebel and Usurper in Kish," dalam Representation of Political Power: Case Histories from Times of Change and Dissolving Order in the Ancient Near East, ed. Marlies Heinz dan Marian H. Feldman (Indiana: Eisenbrauns, 2007), 67-88.
} 
tindakan terorisme bahkan diperakui lebih dahsyat berbanding kesan fizikal. ${ }^{2}$

Terorisme berakar dari bahasa Latin, terrere yang bermaksud 'untuk menjadikan gementar atau ketakutan.' Pertubuhan Bangsa-Bangsa Bersatu (PBB) menghuraikan kegiatan terorisme sebagai apa sahaja perbuatan yang bertujuan untuk menyebabkan kematian atau kecederaan yang teruk kepada orang awam atau individu tidak bersenjata dengan tujuan untuk menakut-nakutkan masyarakat atau kerajaan. Perbuatan tersebut juga dibuat untuk menghalang atau menghadkan kerajaan atau organisasi antarabangsa dari melakukan apa-apa perbuatan yang menjejaskan kedudukan dan perancangan pelaku dan organisasinya. ${ }^{4}$ Terorisme turut dirujuk sebagai suatu tindakan ancaman kepada nilai-nilai utama yang termaktub dalam piagam $\mathrm{PBB}$ iaitu penghormatan terhadap hak asasi manusia, aturan perundangan yang melindungi orang awam, toleransi manusia dan negara serta penyelesaian konflik secara damai. ${ }^{5}$ Perlakuan keganasan atau terorisme bersifat mencabuli piagam-piagam tersebut.

Definisi yang diberikan oleh Noam Chomsky adalah lebih umum apabila mendefinisikan terorisme sebagai penggunaan pendekatan paksaan dan ancaman kepada sesuatu populasi demi mencapai matlamat politik, agama atau lain-lain. ${ }^{6}$ Berdasarkan definisi ini, terorisme tidak

${ }^{2}$ Gerard Chaliand dan Arnaud Blin, The History of Terrorism: From Antiquity to Al-Qaeda, terj. Edward Schneider (London: University of California Press, 2007), vii.

3

Ibid.; "Terrorism", Cactus2000, https://latin.cactus2000.de/showverb.en.php?verb=terrere, https://en.oxforddictionaries.com/definition/terrorism, diakses 7 Ogos 2017.

4

United

Nations, Terrorism,

http://www.un.org/News/dh/infocus/terrorism/sg\%20high-

level\%20panel\%20report-terrorism.htm, tarikh akses 5 Oktober 2017.

${ }^{5}$ Ibid.

${ }^{6}$ Noam Chomsky, 9-11 (New York: Seven Stories Press, 2001), 19. 
Mohd Khairul Naim, "Kajian Kritis Hubungan Agama \& Pemikiran Terorisme," Afkār Vol. 19 Issue 2 (2017): 73-106

hanya terbatas dilakukan oleh kumpulan teroris atau pengganas bahkan sesebuah negara atau badan antarabangsa boleh turut disebut melakukan keganasan sekiranya ia memenuhi definisi di atas. Namun bagi Robert Pape, definisi terorisme sewajarnya dihadkan kepada penggunaan kekerasan yang dilakukan sesebuah organisasi selain kerajaan berdaulat di mana tindakan tersebut bertujuan menimbulkan rasa takut terhadap sasaran. Definisi terlalu umum seperti yang diutarakan Chomsky boleh menyukarkan penggubal polisi dalam mengekang kegiatan ini di samping membawa kekeliruan kerana tiada pemisahan antara organisasi dengan negara kerana keduaduanya adalah entiti berbeza. ${ }^{7}$

Terorisme berakar dari satu sikap iaitu radikalisme yang merujuk kepada pandangan serta tingkah laku individu yang cenderung kepada perubahan yang bersifat melampau dan ekstrim. Ia suatu prinsip dan pegangan kefahaman bahawa struktur sosial dan politik masyarakat perlu diubah secara revolusi dan keyakinan bahawa sistem nilai sedia ada perlu diubah pada aspek dasarnya dengan penggantian sistem nilai baru. Pendekatan mengubah sesuatu secara drastik dan pembasmian nilai lama secara total ini kadang-kala memerlukan suatu pendekatan lain yang disebut sebagai terorisme.

Abad ke-21 ini menyaksikan terorisme mula mendapat perhatian serius oleh masyarakat dunia. ${ }^{8}$ Ini terjadi apabila berlakunya peningkatan kegiatan keganasan khususnya di negara-negara Barat dengan kemuncaknya adalah seperti yang terjadi di New York, Amerika Syarikat pada 11

${ }^{7}$ Robert A. Pape, "The Strategic Logic of Suicide Terrorism", American Political Sciense Review, vol. 97 no. 3, 2003, 345.

${ }^{8}$ Kajian yang dilakukan oleh Neil G. Bowine menyenaraikan terdapat 60 rangkaian inventori data berkenaan pengganas serta kegiatan keganasan di seluruh dunia dari tahun 1968 sehingga 2017. Sila rujuk Neil G. Bowie, "Terrorism Events Data: An Inventory of Databases and Data Sets, 1968-2017," Perspectives on Terrorism vol. 11 no. 4 (2017), 50-72. 
September 2001 dan rangkaian serangan lain di lokasi yang lain sehingga kini.

Berdasarkan kajian-kajian terkini antaranya seperti yang diterbitkan oleh Terrorism Research Initiative menunjukkan berlaku evolusi dalam sel-sel pertubuhan pengganas dari sekadar sebuah kumpulan kecil kepada pertubuhan yang mempunyai jaringan antarabangsa di seluruh dunia sehinggalah kepada wujudnya sebuah negara de facto seperti yang berlaku di beberapa wilayah di Syria dan Iraq kini. ${ }^{9}$ Dengan kemajuan teknologi, akses pengangkutan yang lebih mudah serta dana yang banyak, jaringan ini mempunyai perancangan strategi yang tersusun bagi menjalankan aktiviti mereka termasuklah dengan melaksanakan propaganda dan usaha perekrutan bagi menarik anggota atau simpatisan kepada pertubuhan mereka.

Terdapat lebih dari 200 kajian yang telah dijalankan bagi mengkaji faktor pendorong kepada kegiatan terorisme. $^{10}$ Hasil kajian adalah berbeza dengan sebahagiannya melihat faktor agama, politik dan ekonomi sebagai antara faktor pendorong terhadap kegiatan terorisme. Berdasarkan pengamatan penulis, faktor seperti politik dan ekonomi sukar dikenal pasti kerana ia berkait peribadi dan pandangan seseorang yang terlibat dengan terorisme tersebut khususnya apabila data perlu dikumpul melalui temubual dan observasi secara langsung. Maka, faktor yang lebih mudah dipersepsi dan berskala sejagat ialah agama. Teks agama serta pengamalan sebahagian penganut kononnya sebagai justifikasi kepada teks tersebut dijadikan hujah bahawa agama membenarkan beberapa perlakuan termasuklah terorisme.

\footnotetext{
${ }^{9}$ Terrorism Research Initiative and the Center for Terrorism and Security Studies, Perspectives on Terrorisme (Journal), http://www.terrorismanalysts.com/pt/index.php/pot.

${ }^{10}$ Judith Tinnes, "Bibliography: Root Causes of Terrorism," Perspectives on Terrorism vol. 11 no. 4 (2017), 102-142.
} 
Mohd Khairul Naim, "Kajian Kritis Hubungan Agama \& Pemikiran Terorisme," Afkār Vol. 19 Issue 2 (2017): 73-106

Atas asas tersebut, media serta ahli-ahli politik berkepentingan memainkan peranan menyebarkan mesej berkenaan 'bahaya' agama terhadap manusia. Kewujudan pertubuhan agama seperti Jewish Zealots dan kelompok Hasyasyin (assassins) dari mazhab Syiah Isma'iliyyah suatu waktu dahulu disebut bukti impak agama terhadap kewujudan kelompok pengganas. $^{11}$ Tambahan pula kemunculan kumpulan pengganas seperti al-Qaeda, ISIS dan lain-lain kini yang menggunakan sentimen keagamaan dengan berpanjikan kalimah syahadah dijadikan hujah ancaman agama khususnya Islam terhadap masyarakat sejagat. Namun apakah benar pandangan sedemikian?

Makalah ini akan mengkaji hubungan agama dengan terorisme khususnya naratif yang menjadi faktor munculnya pandangan mengenai perhubungan tersebut. Ia turut menghuraikan kajian terkini oleh beberapa pertubuhan penyelidikan berhubung faktor pendorong penglibatan teroris, analisis terhadap penemuan tersebut serta sudut pandang Islam sebagai sebuah ajaran agama yang dimomokkan dengan terorisme berkenaan aspek keganasan dan kedamaian.

\section{Perkembangan Naratif hubungan Agama dan Terorisme}

Sejarah ajaran Kristian dan perkembangan ajaran tersebut di dunia Barat telah menyaksikan penggunaan pendekatan kekerasan atas nama agama bermula pada kurun ke lima apabila Bishop Augustine of Hippo telah mengeluarkan arahan perang agama yang pertama dalam sejarah Kristian menentang penganut Kristian yang disebut menyeleweng di utara Afrika. Kelompok yang dinamakan sebagai Donatist bersempena pengasasnya yang bernama Donatus Magnus ini telah mempertikaikan kedudukan heirarki gereja, bahkan melihat peranan institusi tersebut adalah suatu yang tidak diperlukan kerana setiap penganut mampu menerima

\footnotetext{
${ }^{11}$ Chaliand dan Blin, The History of Terrorism, viii.
} 
panduan dari Tuhan tanpa memerlukan agamawan sebagai perantara.

Bagi Donatus, manusia yang memiliki keautoritarian atas hal spiritual dan keagamaan akan mudah memanipulasi kuasa yang mereka miliki. Augustine melihat pandangan ini perlu dihalang dengan menggunakan jalan kekerasan. ${ }^{12}$ Beliau menggunakan hujah Perumpamaan tentang Perjamuan Perkahwinan (Parable of the Great Banquet) dalam Perjanjian Baru, Matthew: 22:1-14 sebagai justifikasi penggunaan hukuman dan kekerasan sebagai 'pendidikan' kepada kelompok tersebut. ${ }^{13}$ Ia menjadi detik awal kepada sejarah keganasan atas nama agama Kristian kerana hujah sama digunakan oleh penguasa Rom yang menghukum penganut agama pagan, The Spanish Inquisition terhadap mereka yang disebut menyelewengkan agama serta kekerasan gereja terhadap penduduk asli Amerika yang enggan menukar kepercayaan mereka. ${ }^{14}$ Ia membentuk naratif awal masyarakat Barat berkenaan perkaitan Kristian secara khusus dan agama lain selepas itu secara umum dengan tindakan keganasan.

Naratif ini terus berkembang dengan berkembangnya sekularisasi termasuk dalam bidang keilmuan. Sekularisasi turut berlaku terhadap agama, apabila pengkajian terhadap agama tidak lagi dilihat bersumberkan kepada agama tersebut. Al-Attas mendefinisikan sekularisme sebagai

12 Robert Van de Weyer, Islam and the West: A New Political and Religious Order post September 11 (Kuala Lumpur: Synergy Books, 2001), 85.

${ }^{13}$ Lihat Parable of the Great Banquet, The New International Translation (NIV) Bible, Matthew 22, The International Bible Society, https://www.biblica.com/bible/?osis=niv:Matthew.22:1\%E2\%80\%93 14:1, tarikh akses 9 Oktober 2017. Lihat juga Matius 22, Alkitab (Jakarta: Lembaga Alkitab Indonesia, 2007), 28.

14 John Teehan, In the Name of God: The Evolutionary Origins of Religious Ethics and Violence (Oxford: Wiley-Blackweel, 2010), 170. 
Mohd Khairul Naim, "Kajian Kritis Hubungan Agama \& Pemikiran Terorisme," Afkār Vol. 19 Issue 2 (2017): 73-106

'menghilangkan pesona (agama) dari alam tabii'15. Dalam konteks ini agama direndahkan kedudukannya sebagai sebahagian dari sub-bidang ilmu kemanusiaan. Natijahnya, pengkajian terhadap agama tidak lagi dilihat kepada teks agama tersebut tetapi dinilai menurut bidang dan pendekatan ilmu kemanusiaan dan sains sosial, atas sikap yang melihat agama sebagai produk budaya dan sosial manusia.

Dalam konteks sosiologi agama inilah, Max Weber melihat ajaran agama mempunyai potensi menyebarkan kebencian dan kemarahan penganut terhadap sesuatu. Bahkan disebut nabi dan agamawan melalui 'propaganda' yang disebarkan telah memanfaatkan kekecewaan masyarakat (terhadap kehidupan) supaya mereka berpegang kepada kepercayaan yang mereka ajari. Kebencian atau kekecewaan yang dijadikan 'alat' berpotensi untuk menarik penganut seterusnya disalurkan kepada sikap dan tingkah laku penganut tersebut. ${ }^{16}$

Kemunculan 'social Darwinism', sebuah gerakan yang dipopularkan oleh Herbert Spencer yang mengadunkan pandangan biologi Darwin dengan persekitaran sosial manusia turut memberi impak terhadap pengkajian agama serta naratif hubungannya dengan keganasan. ${ }^{17}$ Impak ajaran agama terhadap psikologi penganutnya dilihat boleh menjadikan seseorang itu fanatik dan berubah dari seorang penganut yang taat kepada pengganas. Friedrich Nietzshe, pendokong faham ateisme moden mendakwa neurosis keagamaan yang wujud boleh menimbulkan gejala yang merbahaya. Agama dilihat

15 Syed Muhammad Naquib al-Attas, Islam and Secularism (Kuala Lumpur: ISTAC, 1993), 18.

${ }^{16}$ Max Weber, "Beberapa Perkara tentang Agama Dunia," dalam Agama dalam Analisis dan Interpretasi Sosiologi, ed. Roland Robertson, terj. Fadilah Ali (Kuala Lumpur: DBP, 1997), 16-17.

${ }^{17}$ Michael Ruse, "The Significance of Evolution," dalam A Companion to Ethics, Peter Singer ed. (Oxford: Blackwell Publishing, 2004), 500. 
menyebabkan kekejaman, dari pengorbanan manusia untuk dewa yang disembah sehingga kepada pembunuhan sesama mereka. Baginya, yang patut dikorbankan ialah 'Tuhan' itu sendiri. Bahkan beliau meramalkan teisme di Eropah tidak akan bertahan lama kerana agama dan 'Tuhan' tidak akan pernah dapat memuaskan kehendak manusia bahkan sebaliknya hanya menimbulkan kegelisahan dan kekejaman. ${ }^{18}$

Hujah sama digunakan oleh Richard Dawkins yang melihat agama sebagai sumber dan punca kepada semangat melampau dan kemudiannya tindakan keganasan terhadap orang lain. Bagi beliau, kedudukan agama yang dipandang absolut menjadikan agama tersebut walau dipandang paling sederhana sekalipun tetap berpotensi melahirkan penganut yang fanatik terhadap anutannya sehingga sanggup melakukan kegiatan keganasan. ${ }^{19}$ Beliau bahkan menempelak ahli politik Barat yang mengelak menyebut agama sebagai punca keganasan dan cuba menggunakan alasan lain. Perang terhadap terorisme menurut beliau seharusnya ditukar kepada perang terhadap agama. Dengan mengambil petikan akhbar berkenaan kes-kes pengebom bunuh diri beliau cuba menunjukkan agama sebagai faktor utama manusia terjebak dengan kegiatan ini. Ungkapan Voltaire, "those who can make you believe absurdities can make you commit atrocities" dijadikan hujah bagaimana agama disebut mampu memperdaya penganutnya melakukan perkara keji yang dipandang terpuji. ${ }^{20}$

Michel Onfray dalam karyanya Atheist Manifesto menuduh Muslim sebagai manusia yang dahagakan darah serta mendefinisikan jihad sebagai holy war. Jihad disebut menjustifikasikan muslim untuk membunuh mereka yang

\footnotetext{
${ }^{18}$ Friedrich Nietzsche, Beyond Good and Evil, terj. Robert Holub (New York: Oxford University Press, 1998), 63-64.

${ }^{19}$ Richard Dawkins, The God Delusion (London: Transworld Publishers, 2006), 342-344.

${ }^{20}$ Ibid., 345.
} 
Mohd Khairul Naim, "Kajian Kritis Hubungan Agama \& Pemikiran Terorisme," Afkār Vol. 19 Issue 2 (2017): 73-106

tidak seagama. Penulis turut menyamakan konsep Dar alIslam serta Dar al-Harb yang diwacanakan dalam karya fiqh dengan gagasan idea Hitler. ${ }^{21}$ Dengan pesimisme yang melampau terhadap agama, karya ini turut meletakkan Yahudi sebagai agama yang mengasaskan 'perang suci', demi membunuh manusia yang berbeza anutan atas nama Tuhan, dan melihat Kristian sebagai ajaran yang mengasaskan faham kebencian kepada bangsa Yahudi (anti semitisme). ${ }^{22}$

Semua ini bagi menonjolkan kegagalan agama menjaga keselamatan manusia bahkan sebaliknya 'menggalakkan' pembunuhan dan keganasan. Tidak cukup dengan itu dalam aspek politik dan demi mendapat sokongan rakyat dan membenarkan justifikasinya menjalankan pencerobohan di Iraq dan Afghanistan, ahli politik seumpama George W. Bush menyamakan kempennya menentang keganasan (war on terror) dengan crusade sehingga menjarakkan lagi hubungan Islam-Barat dan mengaitkan kelompok ekstrimis dan teroris dengan umat Islam. ${ }^{23}$ Istilah 'jihadist' dan 'terrorist' digunakan bertukar ganti oleh media antarabangsa untuk memperlihatkan dekatnya faham jihad dalam Islam dengan terorisme.

Serangan tajam terhadap agama melalui pandanganpandangan yang dikemukakan di atas sudah pasti memerlukan suatu jawapan tuntas dari pihak penganut agama sendiri. Dalam hal ini, beberapa tokoh agama khususnya di Barat yang berdepan secara langsung dengan

21 Michel Onfray, Atheist Manifesto: The Case against Christianity, Judaism and Islam, terj. Jeremy Leggatt (New York: Arcade Publishing, 2007), 199-200.

22 Ibid., 178-179.

23 Peter Waldman dan Hugh Pope, “'Crusade' Reference Reinforces Fears War on Terrorism Is against Muslims," The Wall Street Journal, 21 September 2001, https://www.wsj.com/articles/SB1001020294332922160. 
ancaman naratif negatif terhadap agama ini cuba melakukan pengharmonian.

Hans Kung, seorang tokoh teologi Kristian abad moden ini melihat setiap dakwaan seperti yang dikemukakan di atas tidak sepenuhnya salah dan tidak sepenuhnya juga memperlihatkan wajah agama yang sebenar. Bagi beliau, perbincangan perlu kembali dengan melihat kedudukan ajaran agama itu sendiri. Menurut Küng, berdasarkan penelitiannya terhadap sejarah agamaagama, maka beliau merumuskan bahawa setiap agama mempunyai sisi baik dan sisi jahat. Dalam bukunya Global Responsibility, beliau menyebut ${ }^{24}$ :

"... the question of truth and falsehood cannot be dismissed in a religion, in any religion. Think of all that is taught and practiced in the name of the religions. There is no innocent religion. All religions have their pluses, and they also have their minuses."

Bagi Küng setiap agama tanpa terkecuali mempunyai aspek positif dan negatif. Dari sisi positif, agama menyumbang kepada pembangunan kehidupan berkualiti manusia (human liberation) seperti menyemai sikap toleransi, kebebasan, kemurahan hati, memberi komitmen kepada hubungan sosial, menggalakkan perkembangan spiritual, mereformasi sosial dan menjamin keamanan dunia. Dari sisi negatif, agama pada masa lalu dikatakan terbukti bersifat autoritarian dan tirani. Ia menyebarkan pemikiran sempit, tiada toleransi, tiada keadilan dan ada ketikanya mencetuskan kebimbangan kepada manusia atas hukuman dan peraturannya. Ia menghalalkan perbuatan

${ }^{24}$ Hans Kung, Global Responsibility: In Search of a New World Ethic terj. John Bowden (Oregon: Wipf and Stock, 1991), 83. Lihat juga Mohd Khairul Naim Che Nordin, "Kesederhanaan Beragama menurut Hans Kung," Jurnal Akidah dan Pemikiran Islam (AFKAR), 18(2) $2017,152$. 
Mohd Khairul Naim, "Kajian Kritis Hubungan Agama \& Pemikiran Terorisme," Afkār Vol. 19 Issue 2 (2017): 73-106

tidak bermoral, penyalahgunaan sosial dan mencetuskan peperangan antara manusia. ${ }^{25}$

Berdasarkan kenyataan ini, agama mampu memberi kesan yang baik serta buruk untuk manusia. Oleh kerana ia merupakan kepercayaan manusia maka ia mampu memberi kesan yang sangat membekas dalam diri setiap penganut. Kesan buruk agama kepada manusia ditonjolkan melalui kesan agama yang mampu melahirkan sikap fanatik dan 'superior' kepada diri sendiri sehingga akhirnya mampu mencetuskan peperangan dan keganasan. ${ }^{26}$ Walaupun beliau cuba mengharmonikan dua pendekatan berbeza iaitu antara mereka yang menyokong agama dengan yang menentangnya namun, dengan pengertian agama seperti di atas ia telah dilihat sebagai ajaran yang tidak sempurna, produk sejarah manusia yang mencetuskan peperangan, terbuka kepada kesalahan dan sebahagian ajarannya melahirkan sikap buruk kepada para penganut. Secara tidak langsung ia seakan menyetujui hujah Dawkins di atas.

Persoalannya apakah benar agama menyemarakkan permusuhan dan menjadi penyebab keganasan yang berlaku sehingga kini? Jawapan terhadap persoalan ini sukar dikemukakan untuk setiap agama secara umum, apatah lagi jika ia dikaitkan dengan peristiwa lampau. Walau bagaimanapun kajian-kajian terkini yang dijalankan khusus terhadap pengganas memberikan jawapan yang sebaliknya. Dalam huraian selanjutnya akan dikemukakan

\footnotetext{
${ }^{25}$ Pandangan ini tidak hanya tertakluk kepada agama Kristian khususnya pendirian negatif mereka dalam menolak kemajuan dan sikap autokratik mereka dalam pemerintahan di era pertengahan, tetapi ia turut tertakluk kepada agama-agama yang lain. Menurut Küng, terdapat pengamalan ajaran agama yang tidak mengangkat martabat hak asasi manusia. Sebagai contoh larangan perancangan keluarga oleh Kristian Katolik, layanan tidak adil kepada wanita oleh fundamentalisme Islam, sistem kasta dalam ajaran Hindu dan lain-lain. Ibid., 36, 42 dan 62. Lihat juga Hans Küng, Theology for the Third Millennium: An Ecumenical View (New York: Doubleday, 1988), 238. ${ }^{26}$ Ibid., 62.
} 
perbahasan berkenaan faktor pendorong kepada terorisme dan penggunaan agama sebagai medium mencapai sesuatu tujuan dan matlamat.

\section{Analisis Agama sebagai Faktor Terorisme}

Pandangan para sarjana Barat seperti yang dikemukakan di atas tidak menyediakan bukti konkrit atas dakwaan agama sebagai pendorong terorisme selain mengulangi dakwaan mengenai eksklusivisme agama yang mampu menimbulkan sikap fanatisme penganut sehingga sanggup berbunuhan. Faktor-faktor berlakunya peperangan agama pada masa lampau yang dijadikan contoh bagaimanapun tidak dikemukakan secara jelas. Apakah peperangan yang berlaku ini adalah berpunca dari agama atau terdapat faktor-faktor lain yang mungkin lebih dominan dan menjadi punca utama kepada konflik dan peperangan?

Faktor agama sebagai pencetus konflik ini telah disanggah oleh ramai pihak termasuklah oleh sarjana Barat sendiri. William Cavanaugh sebagai contoh menolak dakwaan bahawa punca pergolakan dan keganasan yang berlaku di seluruh dunia adalah disebabkan pertembungan antara-agama. Beliau menegaskan bahawa tanggapan yang agama mempunyai kecenderungan menggalakkan keganasan adalah lahir dari perspektif masyarakat Barat terhadap agama.

Di Barat, agama dimomokkan sebagai tidak rasional serta memberi dorongan yang bahaya sehingga masyarakat perlu memberi ruang kepada sekularis untuk memegang kuasa. Fanatisme, satu sikap yang didakwa lahir dari kehidupan beragama sering digunakan untuk memaparkan sisi buruk agama. Ia dianggap lawan bagi pemikiran rasional dan keamanan. Tanggapan ini kemudiannya mempengaruhi pelbagai institusi yang ditubuhkan dan polisi yang digariskan, bermula dari usaha menghadkan peranan gereja dalam kehidupan masyarakat Eropah 
Mohd Khairul Naim, "Kajian Kritis Hubungan Agama \& Pemikiran Terorisme," Afkār Vol. 19 Issue 2 (2017): 73-106

sehinggalah usaha terkini pihak barat mempromosi sistem demokrasi liberal di seluruh dunia. ${ }^{27}$

Pandangan berkenaan sisi buruk agama ini disebut oleh Cavanaugh sebagai mitos kerana ia kekal sekadar dakwaan. ${ }^{28}$ Oleh itu, dakwaan agama sebagai pendorong keganasan merupakan sebahagian dari naratif 'enlightenment' barat yang telah berjaya mencipta suatu dikotomi antara agama dan sekularisme. Tanggapan dan tuduhan berkenaan keburukan agama digunakan sebagai justifikasi untuk agama dikesampingkan dalam perkembangan peradaban moden.

Di samping itu, dalam wacana pertentangan ideologi, agama seakan tidak diletakkan sebagai faktor utama kepada keganasan. Bahkan pelopor ideologi saling menyalahkan idea yang berlawanan kerana menyebarkan kezaliman dan keganasan. Vladimir Lenin, seorang ideolog Marxisme mendakwa imperialisasi, peperangan dan keganasan yang berlaku tidak lain kerana dasar-dasar kapitalisme demi mengejar keuntungan firma-firma penjajah. Dasar kapitalis (borjuasi) yang memfokuskan persaingan dan konflik demi mendapat lebih banyak bahan mentah dan pasaran lebih luas akan menyebabkan peperangan yang berterusan. ${ }^{29}$

Sebaliknya, Friedrich A. Hayek berpandangan kezaliman dan pencabulan hak berlaku natijah daripada sistem totalitarian yang asasnya bercambah dari dasar-dasar

27 William T Cavanaugh, The Myth of Religious Violence (Oxford: Oxford University Press, 2009), 3.

${ }^{28}$ Hujah ini digunakan sebagai justifikasi Barat untuk melaksanakan hasrat mereka seperti penubuhan negara-negara bangsa yang liberal (liberal nation-state) di Eropah dan kemudiannya ke seluruh dunia, digunakan untuk meminggirkan sesuatu kelompok atau aliran agama dan untuk menafikan hak pengamalan atau ritual keagamaan sesuatu ajaran. Ibid., 4.

${ }^{29}$ Ian Birchall, Panduan Ringkas tentang Lenin, terj. Muhammad Salleh (t.tp.: Penerbit Bookmarks, 2008), 25-26. 
sosialisme. ${ }^{30}$ Bagi Hayek, ia bermula apabila dasar pemusatan kuasa ditegakkan sehingga manusia yang memegangnya boleh secara wewenang memperlakukan apa yang dikehendaki mereka termasuk melakukan penindasan dan kezaliman. ${ }^{31}$ Agama tidak dilihat sebagai pendorong kepada berlakunya konflik termasuklah terorisme.

Dari sudut faktor peperangan, Azar Gat, seorang pengkaji sejarah peperangan berpandangan bahawa kegiatan keganasan dan peperangan adalah berpunca dari aspek ekonomi dan politik. Bahkan dalam konteks yang lebih umum, punca setiap konflik dan peperangan yang berlangsung sejak wujudnya manusia dikatakan berpunca dari persaingan mendapatkan sumber (bekalan, makanan, ekonomi) serta tempat untuk hidup dan berkembang (negara atau empayar). Sebab-sebab lain dikatakan terbit dari dua punca utama di atas. ${ }^{32}$

Selain itu, tiga jilid ensiklopedia peperangan yang ditulis oleh Charles Phillips dan Alan Axelrod menjelaskan faktor politik dan ekonomi lebih berkecenderungan mempromosikan keganasan berbanding agama. Ensiklopedia tersebut menghimpunkan sebanyak 1,763 peperangan yang telah meletus sepanjang sejarah manusia. Dari jumlah tersebut hanya 123 peperangan (6.98\%)

30 Friedrich A. Hayek, Jalan Perhambaan dan Esei tentang Para Intelektual dan Sosialisme, terj. Al-Mustaqeem M. Radhi (Kuala Lumpur: IDEAS, 2013), 46-47.

${ }^{31}$ Ibid., 48.

32 Azar Gat, War in Human Civilization, Oxford: Oxford University Press, 2006, 87-88 dan 637. Lihat juga Paul Joseph, War in Human Civilization (Review), Social Force, bil. 4, Jun 2008, Oxford University Press, 1861-1863 dan William R. Thompson, War in Human Civilization by Azar Gat, The International History Review, bil. 4, Disember 2007, 841-843. Vox Day, The Irrational Atheist (Dallas: BenBella Books, 2008), 103-106. Untuk statistik jumlah kematian akibat penindasan pemerintah authoritarian terhadap rakyat, lihat R. J. Rummel, Death by Government (New Jersey: Transaction Publishers, 2009), 8. 
Mohd Khairul Naim, "Kajian Kritis Hubungan Agama \& Pemikiran Terorisme," Afkār Vol. 19 Issue 2 (2017): 73-106

dikatakan meletus atas sebab agama manakala selebihnya berdasarkan faktor-faktor yang lain. Jumlah kehilangan nyawa akibat peperangan kerana politik dan ekonomi juga dicatatkan jauh lebih banyak berbanding peperangan yang didakwa atas nama agama. Antaranya seperti peperangan dunia pertama dan kedua yang berlaku di seluruh pelusuk dunia, perang 30 tahun Eropah, Pemberontakan Taiping di China, perang Korea, perang Vietnam, perang sivil di Rusia, pencerobohan Amerika di Iraq dan Afghanistan dan lain-lain yang memakan korban ratusan juta nyawa. ${ }^{33}$

Bahkan dalam siri peperangan salib penuh keganasan yang dilancarkan oleh pihak Kristian dari Barat itupun masih dipersoalkan motif ianya berlaku, sama ada atas faktor agama seperti yang dicanangkan ataupun atas faktor ekonomi dan politik. ${ }^{34}$ Yang jelas, suatu surat yang ditulis oleh panglima tentera salib iaitu Stephen of Blois kepada isterinya menceritakan bahawa beliau telah menerima pelbagai ganjaran dan sanjungan dari maharaja serta memperoleh lebih banyak emas dan perak berbanding kehidupannya di Barat. ${ }^{35}$ Kewujudan 'Papal State' di pesisiran Mediterranean yang mana siri-siri penawanan itu dibiayai oleh orang-orang Itali tidak lain demi memonopoli laluan perdagangan dunia dari tangan penguasa Muslim. ${ }^{36}$

Walaupun perkaitan peperangan dengan terorisme boleh diperbahaskan namun hujah yang mengatakan agama sebagai faktor terorisme adalah bertitik tolak dari pandangan yang melihat berlakunya peperangan atas nama agama pada masa dahulu sebagai contoh sisi buruk agama.

\footnotetext{
${ }^{33}$ Vox Day, The Irrational Atheist (Dallas: BenBella Books, 2008), 103106. Untuk statistik jumlah kematian akibat penindasan pemerintah autoritarian terhadap rakyat, lihat R. J. Rummel, Death by Government (New Jersey: Transaction Publishers, 2009), 8.

34 Jonathan Philips, "The Crusades: A Complete History," History Today, vol 64, issue 5 (2015), http://www.historytoday.com/jonathanphillips/crusades-complete-history

${ }^{35}$ Ibid.

${ }^{36} \mathrm{Ibid}$.
} 
Namun jelas kelihatan faktor-faktor politik kekuasaan dan ekonomi menjadi faktor kepada berlakunya benturan atau pertembungan peradaban yang darinya berlaku peperangan, terorisme dan lain-lain sejak zaman lampau sehingga kini.

Oleh kerana nama dan panji agama digunakan maka agama dinisbahkan kepada konflik yang berlaku. Edward Said dalam karyanya Orientalism telah sedia mencermati kaedah yang digunakan oleh orientalis dalam mengungkap ajaran Islam khususnya iaitu dengan melihat muslim sebagai subjek kajian dan bukan kepada ajaran itu sendiri. Islam dalam konteks ini telah 'disajikan' secara salah. ${ }^{37}$

Namun apakah terdapat bukti bahawa agama bukan pendorong kepada terorisme? Tidakkah beberapa kumpulan pengganas yang wujud pada masa kini menyatakan perjuangan mereka sebagai jihad meninggikan kalimah Allah? Dalam bahagian seterusnya akan dihuraikan beberapa kajian yang menyelidiki faktor keterlibatan ahli kumpulan ini dengan terorisme.

\section{Kajian Emperikal Hubungan Agama sebagai Faktor Terorisme}

Kajian awal mengenai faktor pencetus terorisme khususnya pasca peristiwa 11 September telah dilakukan oleh Robert Pape, seorang profesor sains politik di University of Chicago dan pengasas Chicago Project on Security and Terrorism iaitu institut kajian yang memfokuskan penyelidikan mengenai terorisme dan keselamatan antarabangsa (international security). ${ }^{38}$ Hasil kajian tersebut menjelaskan bahawa terorisme yang berlaku khususnya pada masa kini bukanlah disebabkan oleh faktor

${ }^{37}$ Edward Said, Orientalisme (Bandung: Penerbit Pustaka, 2001), 356.

${ }^{38}$ Profesor Dr Robert A. Pape merupakan pengarah Graduate Studies for Political Science, University of Chicago dan pengarah bersama Program on International Security Policy. Beliau mengasaskan laman sesawang Chicago Project on Security and Terrorism, diakses 7 Januari 2013, http://cpost.uchicago.edu/bob.php. 
Mohd Khairul Naim, "Kajian Kritis Hubungan Agama \& Pemikiran Terorisme," Afkār Vol. 19 Issue 2 (2017): 73-106

agama tetapi atas faktor sekular iaitu sifat nasionalisme yang dimiliki oleh mereka yang terlibat.

Ia tercetus hasil kehendak untuk melindungi dan mengekalkan institusi politik, agama dan sosial negara mereka serta bermatlamat supaya negara yang menyerang negara mereka mengundurkan tentera dan secara langsung memberi pengajaran atas pencerobohan ketenteraan yang dilakukan. ${ }^{39}$

Pape melakukan kajian terhadap lebih kurang 2200 kegiatan terorisme bunuh diri (suicide terrorism) yang berlaku di seluruh dunia mulai tahun 1980 hingga tahun 2009. Beliau juga menemubual beberapa pelaku yang terlibat dan mencari punca kepada berlakunya aktiviti ini. Beliau merumuskan bahawa kempen anti keganasan (the war on terror) yang dilancarkan oleh Amerika Syarikat sebagai mengecewakan dan 'counter-productive' kerana gagal menemui punca sebenar di sebalik keganasan yang berlaku sehingga mereka menyalahkan kumpulan fundamentalis Islam semata-mata sebagai penyebabnya. Hasilnya, kegiatan keganasan dilaporkan semakin bertambah setiap kali kempen anti terorisme ini dilancarkan.

Data-data yang ditemui oleh Pape menemukan bahawa terdapat hubungan yang kecil antara terorisme bunuh diri dengan 'fundamentalisme Islam' atau agamaagama yang lain. Bahkan kumpulan yang paling banyak melakukan kegiatan ini ialah kumpulan Tamil Tiger di Sri Lanka iaitu kumpulan Marxist-Leninist yang menolak kehidupan beragama. Kajian tersebut merumuskan bahawa agama hanyalah faktor kecil di sebalik kegiatan keganasan yang berlaku dan mereka yang terlibat bukanlah hanya di

\footnotetext{
${ }^{39}$ Pape dan Feldman. Robert A. Pape Dying to Win: The Strategic Logic of Suicide Terrorism (New York: Random House, 2005) dan Robert A. Pape dan James K. Feldman, Cutting the Fuse: The Explosion of Global Suicide Terrorism and How to Stop it (London: The University of Chicago Press, 2010), 11-30 dan 43-45.
} 
kalangan mereka yang taat beragama tetapi juga golongan sekularis. Namun apakah rasional atau logik di sebalik tindakan terorisme yang dilakukan sehingga ke tahap membunuh diri sendiri?

Dalam hal ini, Pape merumuskan kegiatan terorisme dilakukan secara terancang dan sistematik. Ia tidak dilakukan oleh individu pelampau yang memilih sesuatu tempat secara rambang dan kemudian melakukan serangan kepada sasaran rambang, sebaliknya setiap tempat yang dipilih telah dirancang. Perancangan ini memiliki motif politik yang jelas, di mana kebiasaannya selepas kegiatan terorisme berhasil dilakukan mereka akan mengisytiharkan motif politik di sebalik tindakan tersebut dan akan terus melakukannya selagi tujuan tersebut tidak tercapai. Kewujudan kegiatan terorisme secara berganda yang berlaku kini adalah kerana kumpulan tersebut melihat keberhasilan taktik ini dalam mencapai matlamat yang mereka kehendaki.

Pape menyenaraikan beberapa kes seperti keputusan Amerika Syarikat dan Perancis mengundurkan tentera mereka di Lubnan, keputusan Sri Lanka untuk memerdekakan negeri Tamil dan keputusan Israel berundur dari Gaza dan Tebing Barat di mana keberhasilan ini dicapai selepas berlaku beberapa siri pengeboman bunuh diri yang akhirnya mendesak pihak terlibat tunduk kepada kemahuan mereka. ${ }^{40}$ Hal ini terbukti apabila kegiatan terorisme sebelum 1980-an dikenal pasti jarang berlaku sehinggalah apabila tercetusnya kejadian serangan kedutaan Amerika Syarikat di Lubnan pada tahun 1983 maka kegiatan terorisme berlaku dengan lebih banyak dan berterusan di seluruh dunia.

Oleh itu, terdapat faktor lebih besar yang mendorong kegiatan ini iaitu semangat nasionalisme yang membuak akibat campur tangan ketenteraan pihak asing. Ia merupakan faktor sepunya yang dikongsi oleh golongan

${ }^{40}$ Pape, The Strategic Logic, 343. 
beragama dan juga sekularis. ${ }^{41}$ Justeru, Pape merumuskan tindakan negara luar mengekang terorisme dengan menduduki negara mereka dilihat tidak menyelesaikan masalah bahkan meningkatkan lagi kegiatan terorisme.

Kajian lebih terkini berkenaan terorisme telah dijalankan oleh United Nations Office of CounterTerrorism, sebuah pertubuhan di bahawa Pertubuhan Bangsa-Bangsa Bersatu pada tahun 2017. Mereka telah menjalankan satu kajian yang dinamakan "Enhancing the Understanding of the Foreign Terrorist Fighters Phenomenon in Syria" di mana ia bertujuan mengetahui dan memahami fenomena global berkaitan kemunculan pengganas asing yang terlibat dalam konflik ketenteraan di Syria (transnational terrorism). ${ }^{42}$ Ia merekodkan faktorfaktor ahli kumpulan pengganas ini keluar dari negara mereka dan terlibat dengan kegiatan terorisme di Syria serta alasan dan justifikasi mereka untuk keluar dari kumpulan tersebut dan kembali ke negara mereka walaupun gagal mencapai tujuan dan matlamat seperti yang diingini.

Bagi mendapatkan input yang absah dan sahih maka PBB telah berhubung secara langsung dengan 43 individu yang terlibat dari 23 negara berbeza. Hasil kajian menunjukkan subjek terlibat adalah di kalangan belia, lelaki dan tidak menerima pengajian peringkat tinggi. Subjek sebahagian besarnya kurang pendidikan, mempunyai pendapatan yang rendah di negara asal, ada sebahagiannya tidak bekerja dan tidak mempunyai prospek kerjaya walaupun datang dari negara Barat. ${ }^{43}$ Bahkan mereka juga dikenal pasti hanya memiliki kefahaman peringkat asas berkenaan pengajian Islam. ${ }^{44}$

\footnotetext{
${ }^{41}$ Pape, Dying to Win, 2.

42 United Nations Office of Counter-Terrorism, "Enhancing the Understanding of the Foreign Terrorist Fighters Phenomenon in Syria”, 2017.

${ }^{43}$ Ibid., 26-31.

${ }^{44}$ Ibid., 37.
} 
Kajian juga menemui sebahagian besar subjek lahir dari keluarga besar yang 'tidak berfungsi', tinggal terasing dari komuniti sosial, ekonomi dan politik. Laporan menunjukkan sebahagian subjek mempunyai masalah identiti dan psikologi yang walaupun tidak kronik tetapi tetap bermasalah, apatahlagi dengan lingkungan kehidupan mereka di usia remaja yang tidak kondusif pada aspek sosial dan ekonomi serta tidak mempunyai 'role model' akibat kegagalan rumah tangga ibu bapa. Individu seperti ini dikenalpasti mangsa paling mudah untuk ditarik kerana mereka memerlukan bimbingan dari orang lain yang mampu mengawal psikologi mereka. ${ }^{45}$

Faktor atau motivasi utama penglibatan mereka bermula dengan rasa simpati terhadap penganut seagama yang ditindas. Gambaran kelompok Sunni di Syria yang digambarkan ditekan dan diserang kerana kepercayaan mereka oleh kerajaan Assad yang berfahaman Syiah adalah merupakan tema utama yang mendorong penglibatan mereka. Perasaan ini kemudian berkembang sehingga mereka merasakan suatu kewajipan agama untuk membela kelompok sealiran yang tertindas. ${ }^{46}$ Namun ia boleh disifatkan sebagai suatu semangat semata kerana dikenalpasti dari kajian ini, mereka bukanlah di kalangan muslim yang taat dalam beragama. Kesedaran beragama itu muncul khususnya selepas Arab Spring pada tahun 2011 manakala pengetahun mereka mengenai konsep jihad melalui temubual yang dijalankan adalah sangat cetek. ${ }^{47}$

Oleh itu, faktor-faktor seperti kualiti pendidikan dan kefahaman berkenaan ajaran Islam yang rendah, status ekonomi yang juga rendah, rasa terpinggir dari aspek sosial di negara asal, kegagalan keluarga dan ditambah dengan semangat beragama yang mahu membantu saudara seagama yang dilihat ditindas atas faktor aliran yang

\footnotetext{
${ }^{45}$ Ibid., 27

${ }^{46}$ Ibid., 5-6.

${ }^{47}$ Ibid., 35.
} 
Mohd Khairul Naim, "Kajian Kritis Hubungan Agama \& Pemikiran Terorisme," Afkār Vol. 19 Issue 2 (2017): 73-106

dipegang merupakan ramuan yang melahirkan tekad kepada mereka untuk terlibat dengan kegiatan terorisme. Faktor agama seperti kepentingan mendirikan negara Islam atau khilafah pula dijadikan justifikasi oleh kumpulan radikal untuk memotivasi dan menyatukan ahli-ahli mereka khususnya dari negara-negara asing. ${ }^{48}$

Dari kajian ini juga dirumuskan ahli-ahli bawahan adalah dalam kalangan mereka yang rendah mutu pendidikannya, namun di peringkat pimpinan dikenalpasti mereka melalui peringkat pengajian tinggi. Aktiviti terorisme yang terancang dan strategik dirancang oleh kumpulan pimpinan manakala pelaksananya dalam kalangan ahli yang mudah dipengaruhi. Dalam konteks ini apakah pula pendirian pimpinan khususnya dari kelompok terorisme dalam menjustifikasikan tindakan tersebut? Mereka menggunakan hujah kewajipan menegakkan negara Islam dengan meruntuhkan negara kufur (Dār alIslām dan Dār al-Kufr) sebagai antara tema perjuangan. Dalam perbincangan seterusnya, akan dikupas pula berkenaan perspektif Islam berkenaan terorisme serta persoalan berkait kekuasaan dalam Islam.

\section{Perspektif Islam berkenaan Terorisme}

Ajaran Islam merupakan ajaran yang menyebarkan nilainilai luhur. Perutusan Nabi Muhammad SAW ke dunia ini adalah sebagai rahmat ke sekalian alam seperti yang termaktub dalam firman Allah SWT surah al-Anbiya' ayat 107 yang bermaksud: "Dan tiadalah Kami mengutus kamu, melainkan untuk (menjadi) rahmat bagi sekalian alam."

Secara terminologinya maksud rahmat ialah pengampunan, ihsan, kebaikan dan nikmat. Menurut alQurțūbi, al-Ṭabari dan mufassirín yang lain, maksud ayat Nabi membawa kerahmatan ini bukan sekadar untuk golongan beriman tetapi juga meliputi non-muslim iaitu

${ }^{48} \mathrm{Ibid} ., 36$. 
setiap manusia memperolehi kebaikan dengan perutusan Baginda SAW. ${ }^{49}$

Oleh itu, kedatangan Islam bukan suatu pertembungan, benturan atau konflik dengan peradaban yang lain. Ia datang untuk menyampaikan petunjuk dan menyebarkan kasih sayang melalui dialog antara bangsabangsa yang berbeza sesuai dengan firman-Nya dalam surah al-Hujurat ayat 13 yang bermaksud: "Wahai manusia, sesungguhnya Kami menciptakan kamu dari seorang lelaki dan seorang perempuan dan menjadikan kamu berbangsabangsa dan bersuku-suku supaya kamu saling kenalmengenal. Sesungguhnya orang yang paling mulia di antara kamu di sisi Allah ialah orang yang paling bertakwa di antara kamu." Justeru, hubungan dan interaksi antara agama, budaya dan peradaban lain bukan terhad kepada peperangan semata tetapi ia lebih luas meliputi pertukaran budaya, sinergi pengetahuan dan lain-lain. ${ }^{50}$

Walaubagaimanapun, kenapa muncul perspektif berbeza dalam kalangan umat Islam yang melihat perbezaan sebagai permusuhan, pertentangan dan pertembungan bahkan dengan sesama Muslim sendiri? Kajian yang dilakukan oleh para ilmuwan al-Azhar kontemporari menunjukkan konsep hakimiyyah menjadi dasar atau pijakan seluruh kelompok radikal dalam menjustifikasikan sikap dan tindakan mereka. ${ }^{51}$

49 Muḥammad bin Aḥmad al-Qurțūbí, al-Jāmi' li Aḥkam al-Qur'ān, Sūrah al-Anbiyā', al-Maktabah al-Islamiyyah (Islamweb.net), http://library.islamweb.net/newlibrary/display_book.php?idfrom=235 2\&idto $=2352 \& b k \_n o=48 \& I D=1787$, diakses 9 September 2017, Muhammad bin Jarìr al-Ṭabari, Tafsīr al-Ṭabarí, Tafsì Sūrah alAnbiyā', al-Maktabah al-Islamiyyah (Islamweb.net), http://library.islamweb.net/newlibrary/display_book.php?flag=1\&bk_ no=50\&surano=21\&ayano=107, diakses 9 September 2017.

${ }^{50}$ Usāmah Sayyid al-Azhari, al-Haqq al-Mubīn fí al-Radd 'ala man Talā'aba bi al-Dīn: al-Tayyārāt al-Mutațarrifah min al-Ikhwān ilā alDā 'ish fī Mìzān al- 'Ilm (Abū Dabì: Dār al-Faqīh, 2016), 17.

${ }^{51}$ Ibid. 
Mohd Khairul Naim, "Kajian Kritis Hubungan Agama \& Pemikiran Terorisme," Afkār Vol. 19 Issue 2 (2017): 73-106

Secara umumnya, Hakimiyyah ialah konsep yang bertitik tolak dari akidah Islam yang meyakini Allah SWT yang menetapkan hukum dan syariat-Nya kepada manusia dalam menjalani kehidupan di dunia ini. ${ }^{52}$ Ia keyakinan bahawa hanya Allah berhak menentukan hukum wajib, haram, sunnah dan sebagainya. Dalam hal ini tiada sesiapa yang menjadi sekutu bagiNya dalam menentukan hukumhukum tersebut. Keyakinan ini seterusnya beralih ke ranah fiqh. Perlaksanaan kepada hukum-hukum tersebut termasuklah yang melibatkan ketatanegaraan akan berkait erat dengan faktor lain sehingga ia mampu direalisasikan iaitu seperti sebab, 'illah, syarat, mani' dan lain-lain. Dalam konteks perlaksanaan inilah ada yang melaksanakannya dengan baik dan ada yang tidak di mana ia bergantung kepada situasi dan kondisi tertentu. ${ }^{53}$

Oleh itu, aspek keyakinan berkenaan peletak hukum iaitu Allah SWT adalah suatu dimensi yang membabitkan akidah manakala aspek perlaksanaannya pula tertakluk kepada dimensi fiqh yang tertakluk pula kepada hukum dan syarat tertentu. Dalam persoalan inilah muncul kelompok radikal yang membangunkan paradigma takfiri melalui pemahaman yang salah terhadap permasalahan di atas. Menurut Usamah Sayyid al-Azhari, kelompok ini melihat masyarakat yang kurang sempurna dalam menerapkan hukum-hukum fiqh dianggap telah 'mencederai' hak prerogatif Allah dalam menentukan hukum dan hal itu didakwa sebagai penentangan terhadap-Nya sehingga akhirnya masyarakat ini dikafirkan. ${ }^{54}$

Di samping itu, mereka mengembangkan kefahaman yang salah terhadap al-Quran surah al-Ma'idah ayat 44 yang bermaksud: "Barangsiapa yang tidak berhukum

52 Muhammad Sa`id Ramaḍān al-Būtī, Kubrā al-Yaqīniyyāt alKawniyyah: Wujūd al-Khāliq wa Wazīfah al-Makhlūq (Damsyik: Dār al-Fikr, 1997), 371.

${ }^{53}$ Usāmah, al-Haqq al-Mubīn, 51-52.

${ }^{54}$ Ibid., 21. 
dengan hukum yang diturunkan oleh Allah maka mereka adalah orang-orang kafir." Dalam memahami ayat ini, mereka mengkafirkan sesiapa yang tidak menerapkan hukum Islam, meskipun orang tersebut meyakini bahawa ayat itu benar dan merupakan wahyu dari Allah SWT namun tidak mampu menerapkannya kerana sebab tertentu. ${ }^{55}$

Kefahaman ini sama seperti yang dipegang oleh kelompok Khawarij suatu ketika dahulu dalam mengkafir dan membunuh umat Islam yang tidak sealiran. Mereka menambah satu lagi syarat dalam pokok atau usul iman iaitu hakimiyyah, suatu yang berbeza dan ganjil dengan apa yang disepakati oleh ulama sejak dahulu sehingga kini. ${ }^{56}$ Sedangkan berdasarkan pandangan yang kuat berkenaan ayat di atas, maksud kafir yang dimaksudkan ditujukan kepada mereka yang tidak berhukum dengan hukum Allah kerana menolak hukum tersebut sebagai wahyu yang datang dari-Nya. Manakala orang yang mengakui ayat tersebut merupakan wahyu dari Allah namun tidak mampu melaksanakannya maka dia tidak dihukum kafir. Apatahlagi ada ramai ulama pula yang menyatakan ayat ini ditujukan kepada kelompok ahli kitab. ${ }^{57}$

Secara tuntasnya, Islam menolak sikap dan tindakan melampau apatahlagi berkait terorisme. Imam al-Bukhārī pernah meriwayatkan hadis dari Jābir bin 'Abd Allāh al-

55 Ibid.

${ }^{56}$ Ibid.

${ }^{57}$ Lihat Muhammad bin Jarì al-Ṭabarī, Tafsìr al-Ṭabarī, Tafsīir Sūrah alMā'idah, Bāb al-Qawl fī Ta’wìl Qawluhu Ta āla "wa man lam yahkum bimā anzal Allāh”, al-Maktabah al-Islamiyyah, http://library.islamweb.net/newlibrary/display_book.php?idfrom=158 3\&idto=1583\&bk_no=50\&ID=1591, diakses 9 September 2017; Abū 'Abd Allāh Muḥammad bin Yūsuf al-Andalūsī, al-Baḥr al-Muhịị, Tafsīr Sūrah al-Mā'idah, al-Maktabah al-Islamiyyyah, http://library.islamweb.net/newlibrary/display_book.php?bk_no=62\& $\mathrm{ID}=156 \&$ idfrom $=679 \&$ idto $=696 \&$ bookid $=62 \&$ startno $=7$, diakses 9 September 2017. 
Mohd Khairul Naim, "Kajian Kritis Hubungan Agama \& Pemikiran Terorisme," Afkār Vol. 19 Issue 2 (2017): 73-106

Anșāī berkenaan kisah seorang lelaki membawa dua ekor unta pengangkut air yang berkebetulan waktu itu melihat Mu`az solat. Lalu dia pun berjemaah dengan berimamkan Mu`az. Dalam solat tersebut, Mu`az membaca surah alBaqarah dan al-Nisā'. Akibat terlalu lama, lelaki tersebut meninggalkan Mu`az untuk solat sendirian. Selepas beberapa ketika dia mendengar kritikan Mu`az terhadap tindakannya keluar dari solat berjemaah, lantas diadukan hal tersebut kepada Rasulullah SAW. Nabi menemui Mu`az dan bersabda yang bermaksud: "Wahai Mu`az, apakah kamu menjadi pembuat fitnah?" Baginda mengulanginya sebanyak tiga kali dan kemudian menambah: "Kamu boleh membaca surah al-`Alā, al-Shams dan al-Layl, kerana para makmum di belakangmu di kalangan mereka yang berusia lanjut, lemah dan mempunyai keperluan. ${ }^{58}$

Dari hadis ini, Nabi menyifatkan tindakan sahabat tersebut sebagai munaffir iaitu menjauhkan orang lain dari Islam. ${ }^{59}$ Dalam hadis ini juga baginda memberi piawai atau parameter dalam beribadah iaitu seimbang sehingga ibadah tersebut tidak dipandang enteng dan tidak juga dirasai membebankan. Oleh itu, dalam persoalan ibadat yang membabitkan interaksi dengan orang lain (berjemaah) itupun dipandang penting untuk diamalkan secara sederhana, apatah lagi dalam persoalan-persoalan yang lain. Bahkan hadis ini menunjukkan kekhuatiran Nabi terhadap peribadi yang bersikap melampau dan bersemangat tinggi sehingga mempertikaikan tindakan dan pendirian orang lain. Sikap inilah yang melahirkan pula sikap melampau yang melihat hanya dia sahaja yang benar manakala orang lain salah bahkan sampai ke tahap pengkafiran kepada pihak tidak sehaluan.

\footnotetext{
${ }^{58}$ Lihat Abū 'Abd Allāh Muhammad ibn Ismā'īl al-Bukhārī, Șahịh alBukhārí, Abwāb Șalāt al-Jamā’ah wa al-Imāmāh, Bāb Izā Țūl al-Imām wa kāna li al-Rajul Ḥājah Fakharaja fa Șallā, (Damsyik: Dār Ibn Kathir, 1993), 231.

${ }^{59}$ Usāmah, al-Haqq al-Mubīn, 35
} 
Dalam hal inilah Rasulullah SAW bersabda yang bermaksud: "Dan barangsiapa yang keluar memerangi umatku, lantas membunuh orang baik dan orang jahat, tidak peduli dengan kaum mu'min dan tidak menepati perjanjian dengan ahli zimmah, maka dia bukan sebahagian dariku dan aku bukan sebahagian darinya."60 Hadis ini jelas suatu pesanan kepada umatnya untuk tidak bersikap melampau sehingga sanggup memerangi saudara seagama serta bukan Islam.

Oleh itu, menurut perspektif Islam, ajaran yang dianuti mesti diyakini mampu secara lengkap memberi kemanfaatan kepada diri dan dalam masa yang sama menjauhkan mereka dari keburukan. Sekiranya timbul sikap dan perilaku buruk dalam diri seseorang muslim maka keburukan itu tidak boleh dihalakan kepada agama. Ia mungkin salah tafsiran penganut terhadap ajaran yang sebenar, kejahilannya dalam beramal atau ikutannya terhadap sesuatu adat budaya tetapi dinisbahkan kepada agama. Ini kerana Islam merupakan ajaran yang menyebarkan keimanan melalui kefahaman, kasih sayang dan ikutan seperti yang ditunjukkan oleh Nabi SAW, dan bukannya ajaran yang mengembangkan kebencian, pengkafiran serta pembunuhan.

Justeru, suatu yang tidak wajar apabila menisbahkan kelompok kecil mereka yang terlibat dengan terorisme dengan ajaran Islam sedangkan majoriti umat Islam yang lain tidak pernah terlibat dengan kegiatan sebegini. Apatah lagi jika dilihat kepada Global Terrorism Index yang dilaksanakan oleh Institute for Economy and Peace pada tahun 2016 menunjukkan sembilan dari sepuluh negara yang mencatatkan rekod kematian tertinggi seluruh dunia akibat terorisme ialah dalam kalangan negara umat Islam khususnya yang terlibat dengan konflik ketenteraan.

60 Muslim bin Hajjāj, Șahịh Muslim, Kitāb al-Īmān, Bāb al-Amr bi Luzūm al-Jamā'ah `ind Dhuhūr al-Fitan wa Tahdzīr al-Du’āt ila alKufr (Damsyik: Dār al-Nawādir, 2012), jil. 6, 21. 
Mohd Khairul Naim, "Kajian Kritis Hubungan Agama \& Pemikiran Terorisme," Afkār Vol. 19 Issue 2 (2017): 73-106

Negara Iraq yang berdepan dengan masalah keamanan pasca penggulingan Saddam Hussein oleh Amerika Syarikat dan sekutunya menyaksikan jumlah kematian terbanyak iaitu 6960 orang hanya untuk tahun 2016 sahaja. $^{61}$ Ia diikuti Afghanistan, Nigeria, Pakistan dan Yaman di mana kesemua negara ini berkongsi faktor sepunya yang sama iaitu ketidakstabilan politik dan ekonomi akibat pendudukan asing yang akhirnya membuka vakum kepada lahir dan berkembangnya kumpulan radikal yang menggunakan terorisme sebagai teras perjuangan mereka.

\section{Rumusan}

Berdasarkan perbincangan yang diutarakan di atas, kecenderungan menisbahkan agama khususnya Islam sebagai faktor berlakunya terorisme akan berpotensi mengabaikan faktor-faktor lain yang jauh lebih besar seperti faktor politik dan ekonomi. Agama dalam hal ini hanya digunakan sebagai medium manipulasi sesetengah pihak berkepentingan untuk menjustifikasikan atau menghalalkan perlakuan yang telah mereka lakukan atau setidaknya menjadi dorongan kepada apa yang dilakukan di mana sebenarnya ia berasaskan pemahaman keagamaan yang salah. Kesalahan besar sesetengah pihak ialah apabila 'menyanjung' pengganas dengan mengaitkan tindakan mereka dengan agama. Dengan pendirian sebegini ia membenarkan pandangan yang dipegang oleh mereka bahawa tindakan tersebut sebahagian dari agama. Bahkan permusuhan terhadap agama akan menyebabkan fahaman terorisme terus berkembang.

Terorisme sebaliknya berkembang subur dalam persekitaran yang penuh dengan 'keputusasaan', penindasan dan peminggiran. Ia juga berkembang di tempat berkembangnya konflik serantau dan pendudukan asing. Faktor-faktor inilah yang seharusnya difokuskan bagi

${ }^{61}$ Institute for Economic and Peace, Global Terrorism Index 2016, 25. 
mengekang fahaman terorisme dari berkembang. Dalam konteks Malaysia, suatu kajian khusus perlu dilakukan bagi mengenalpasti faktor keterlibatan rakyat Malaysia dengan kegiatan terorisme. Penglibatan mereka dengan kumpulan militan di luar negara perlu dikaji khususnya pada aspek motif dan tujuan. Persoalan ini penting untuk dijawab supaya usaha pencegahan melalui pendidikan dan pemulihan melalui deradikalisasi boleh digembling oleh kerajaan kerana tindakan penguatkuasaan dan penahanan bukanlah satu-satunya jalan untuk menghapuskan fahaman dan gerakan ini.

\section{Penghargaan}

Makalah ini merupakan sebahagian hasil kajian Geran Penyelidikan Fundamental (FRGS): FP022-2017A. Penulis merakamkan penghargaan kepada Kementerian Pendidikan Malaysia dan Universiti Malaya kerana mendanai dan meluluskan kajian ini.

\section{Rujukan}

Al-Andalūsì, Abū `Abd Allāh Muḥammad bin Yūsuf, alBaḥr al-Muhịt, Tafsīi Sūrah al-Mā'idah, al-Maktabah alIslamiyyyah,

http://library.islamweb.net/newlibrary/display_book.php ?bk_no $=62 \& \mathrm{ID}=156 \&$ idfrom $=679 \&$ idto $=696 \&$ bookid $=$ 62\&startno=7, diakses 9 September 2017.

Al-Attas, Syed Muhammad Naquib. Islam and Secularism. Kuala Lumpur: ISTAC, 1993.

Al-Azharī, Usāmah Sayyid. Al-Haqq al-Mubīn fī al-Radd 'ala Man Talāaba bi al-Dīn: al-Tayyārāt alMutațarrifah min al-Ikhwān ilā al-Dā'ish fî̀ Mīzān al'Ilm. Abū Dabī: Dār al-Faqīh, 2016.

Al-Bukhārī, Abū 'Abd Allāh Muhammad ibn Ismā'īl. Sahih al-Bukhari. Damsyik: Dār Ibn Kathīr, 1993. Al-Būtī, Muhammad Sa ìd Ramaḍān. Kubrā al-Yaqīiniyyāt al-Kawniyyah: Wujūd al-Khāliq wa Wazíifah alMakhlūq. Damsyik: Dār al-Fikr, 1997.

Alkitab. Jakarta: Lembaga Alkitab Indonesia, 2007. 
Mohd Khairul Naim, "Kajian Kritis Hubungan Agama \& Pemikiran Terorisme," Afkār Vol. 19 Issue 2 (2017): 73-106

Birchall, Ian. Panduan Ringkas tentang Lenin, terj. Muhammad Salleh. t.tp.: Penerbit Bookmarks, 2008.

Bowie, Neil G., "Terrorism Events Data: An Inventory of Databases and Data Sets, 1968-2017," Perspectives on Terrorism vol. 11 no. 4 (2017): 50-72.

Cactus2000,

https://latin.cactus2000.de/showverb.en.php?verb=terrer e, https://en.oxforddictionaries.com/definition/terrorism, diakses 7 Ogos 2017.

Cavanaugh, William T. The Myth of Religious Violence. Oxford: Oxford University Press, 2009.

Chaliand, Gerard dan Blin, Arnaud. The History of Terrorism: From Antiquity to Al-Qaeda, terj. Edward Schneider. London: University of California Press, 2007. Chomsky, Noam. 9-11. New York: Seven Stories Press, 2001.

Dawkins, Richard. The God Delusion. London: Transworld Publishers, 2006.

Day, Vox. The Irrational Atheist. Dallas: BenBella Books, 2008.

Gat, Azar. War in Human Civilization. Oxford: Oxford University Press, 2006,

Hayek, Friedrich A. Jalan Perhambaan dan Esei tentang Para Intelektual dan Sosialisme, terj. Al-Mustaqeem M. Radhi. Kuala Lumpur: IDEAS, 2013.

Heinz, Marlies. "Sargon of Akkad: Rebel and Usurper in Kish." Dalam Representation of Political Power: Case Histories from Times of Change and Dissolving Order in the Ancient Near East, ed. Marlies Heinz dan Marian H. Feldman. Indiana: Eisenbrauns, 2007: 67-88.

Institute for Economic and Peace. Global Terrorism Index. 2016.

Joseph, Paul, War in Human Civilization (Review), Social Force, bil. 4, Jun 2008, Oxford University Press. 
Kung, Hans. Global Responsibility: In Search of a New World Ethic, terj. John Bowden. Oregon: Wipf and Stock, 1991.

Küng, Hans. Theology for the Third Millennium: An Ecumenical View. New York: Doubleday, 1988.

Mohd Khairul Naim Che Nordin, "Kesederhanaan Beragama menurut Hans Kung," Jurnal Akidah dan Pemikiran Islam (AFKAR), 18(2) 2017: 149-192.

Muslim bin Hajjāj. Șahịh Muslim, Kitāb al-Īmān, Bāb alAmr bi Luzūm al-Jamā'ah `ind Dhuhūr al-Fitan wa Tahdzīr al-Du`āt ila al-Kufr. Damsyik: Dār al-Nawādir, 2012.

Nietzsche, Friedrich Beyond Good and Evil, terj. Robert Holub. New York: Oxford University Press, 1998.

Onfray, Michel. Atheist Manifesto: The Case against Christianity, Judaism and Islam, terj. Jeremy Leggatt New York: Arcade Publishing, 2007.

Pape, Robert A. dan Feldman, James K. Cutting the Fuse: The Explosion of Global Suicide Terrorism and How to Stop it. London: The University of Chicago Press, 2010. Pape, Robert A. dan Feldman, James K. Dying to Win: The Strategic Logic of Suicide Terrorism. New York: Random House, 2005.

Pape, Robert A., "The Strategic Logic of Suicide Terrorism", American Political Sciense Review, vol. 97 no. 3, 2003.

Philips, Jonathan, "The Crusades: A Complete History," History Today, vol 64, issue 5 (2015), http://www.historytoday.com/jonathanphillips/crusades-complete-history

Al-Qurțūbì, Muḥammad bin Aḥmad, al-Jāmi` li Aḥkam alQur'ān, Sūrah al-Anbiyā', al-Maktabah al-Islamiyyah (Islamweb.net), http://library.islamweb.net/newlibrary/display_book.php ?idfrom $=2352 \&$ idto $=2352 \& b k \_n o=48 \& I D=1787$, diakses 9 September 2017. 
Mohd Khairul Naim, "Kajian Kritis Hubungan Agama \& Pemikiran Terorisme," Afkār Vol. 19 Issue 2 (2017): 73-106

Rummel, R. J. Death by Government. New Jersey: Transaction Publishers, 2009.

Ruse, Michael. "The Significance of Evolution." Dalam $A$ Companion to Ethics, ed. Peter Singer. Oxford: Blackwell Publishing, 2004.

Said, Edward. Orientalisme. Bandung: Penerbit Pustaka, 2001.

Al-Ṭabari, Muhammad bin Jarīr, Tafsīr al-Ṭabari, Tafsìr Sūrah al-Mā'idah, Bāb al-Qawl fī Ta'wìl Qawluh Ta`āla "wa man lam yaḥkum bimā anzal Allāh", al-Maktabah al-Islamiyyah,

http://library.islamweb.net/newlibrary/display_book.php ?idfrom $=1583 \&$ idto $=1583 \&$ bk_no $=50 \& \mathrm{ID}=1591$, diakses 9 September 2017.

Al-Ṭabari, Muhammad bin Jarī. Tafsīr al-Ṭabari, Tafsìr Sūrah al-Anbiyā', al-Maktabah al-Islamiyyah (Islamweb.net),

http://library.islamweb.net/newlibrary/display_book.php ?flag $=1 \&$ bk_no $=50 \&$ surano $=21 \&$ ayano $=107$, diakses 9 September 2017.

Teehan, John. In the Name of God: The Evolutionary Origins of Religious Ethics and Violence. Oxford: Wiley-Blackweel, 2010.

Terrorism Research Initiative and the Center for Terrorism and Security Studies, Perspectives on Terrorisme (Journal),

http://www.terrorismanalysts.com/pt/index.php/pot.

The New International Translation (NIV) Bible, The International Bible Society, https://www.biblica.com/bible/?osis=niv:Matthew.22:1

\%E2\%80\%9314:1, tarikh akses 9 Oktober 2017.

Thompson, William R. War in Human Civilization by Azar Gat, The International History Review, bil. 4, Disember 2007.

Tinnes, Judith, "Bibliography: Root Causes of Terrorism,"

Perspectives on Terrorism vol. 11 no. 4 (2017): 102-142. 
United Nations Office of Counter-Terrorism, "Enhancing the Understanding of the Foreign Terrorist Fighters Phenomenon in Syria", 2017.

United

Nations, Terrorism, http://www.un.org/News/dh/infocus/terrorism/sg\%20hi gh-level\%20panel\%20report-terrorism.htm, tarikh akses 5 Oktober 2017.

Van de Weyer, Robert. Islam and the West: A New Political and Religious Order post September 11. Kuala Lumpur: Synergy Books, 2001.

Waldman, Peter dan Pope, Hugh, "'Crusade' Reference Reinforces Fears War on Terrorism Is against Muslims," The Wall Street Journal, 21 September 2001, https://www.wsj.com/articles/SB100102029433292216 0 .

Weber, Max. "Beberapa Perkara tentang Agama Dunia." Dalam Agama dalam Analisis dan Interpretasi Sosiologi, ed. Roland Robertson, terj. Fadilah Ali. Kuala Lumpur: DBP, 1997. 